\title{
Effectiveness of Intensive Primary Care Interventions: A Systematic Review
}

\author{
Samuel T. Edwards, MD, MPH ${ }^{1,2,3,4}$, Kim Peterson, $M S^{5}$, Brian Chan, $M D, M P H^{3}$, \\ Johanna Anderson, $\mathrm{MPH}^{5}$, and Mark Helfand, $\mathrm{MD}, \mathrm{MS}, \mathrm{MPH}^{1,2,3,5}$
}

'Section of General Internal Medicine, VA Portland Health Care System, Portland, OR, USA; ${ }^{2}$ Center to Improve Veteran Involvement in Care, VA Portland Health Care System, Portland, OR, USA; ${ }^{3}$ Division of General Internal Medicine and Geriatrics, Oregon Health \& Science University, Portland, OR, USA; ${ }^{4}$ Department of Family Medicine, Oregon Health \& Science University, Portland, OR, USA; ${ }^{5}$ Evidence-based Synthesis Program (ESP) Coordinating Center, VA Portland Health Care System, Portland, OR, USA.

BACKGROUND: Multicomponent, interdisciplinary intensive primary care programs target complex patients with the goal of preventing hospitalizations, but programs vary, and their effectiveness is not clear. In this study, we systematically reviewed the impact of intensive primary care programs on all-cause mortality, hospitalization, and emergency department use.

METHODS: We searched PubMed, CINAHL, the Cochrane Central Register of Controlled Trials, and the Cochrane Database of Reviews of Effects from inception to March 2017. Additional studies were identified from reference lists, hand searching, and consultation with content experts. We included systematic reviews, randomized controlled trials (RCTs), and observational studies of multicomponent, interdisciplinary intensive primary care programs targeting complex patients at high risk of hospitalization or death, with a comparison to usual primary care. Two investigators identified studies and abstracted data using a predefined protocol. Study quality was assessed using the Cochrane risk of bias tool.

RESULTS: A total of 18 studies (379,745 participants) were included. Three major intensive primary care program types were identified: primary care replacement (home-based; three RCTs, one observational study, $N=367,681$ ), primary care replacement (clinic-based; three RCTs, two observational studies, $N=9561$ ), and primary care augmentation, in which an interdisciplinary team was added to existing primary care (five RCTs, three observational studies, $N=2503$ ). Most studies showed no impact of intensive primary care on mortality or emergency department use, and the effectiveness in reducing hospitalizations varied. There were no adverse effects reported.

DISCUSSION: Intensive primary care interventions demonstrated varying effectiveness in reducing hospitalizations, and there was limited evidence that these interventions were associated with changes in mortality. While interventions could be grouped into categories, there was still substantial overlap between intervention approaches. Further work is needed to identify program features that may be associated with improved outcomes.

Received February 10, 2017

Revised June 28, 2017

Accepted August 18, 2017

Published online September 18, 2017
KEY WORDS: primary care; primary care redesign; care management; home care; comorbidity.

J Gen Intern Med 32(12):1377-86

DOI: $10.1007 / \mathrm{s} 11606-017-4174-\mathrm{Z}$

(C) Society of General Internal Medicine (outside the USA) 2017

\section{INTRODUCTION}

A small proportion of patients are responsible for a large majority of health care costs, often through frequent hospitalization. ${ }^{1}$ These patients are typically older and suffer from multimorbidity ${ }^{2-4}$ and functional limitations. ${ }^{5,6}$ Such patients may require more frequent primary care visits, care from multiple subspecialists, home care services, or assistance from social workers, pharmacists, or physical therapists to optimize the management of their medical conditions and their overall health. Additionally, as they use more services, the risk of care fragmentation increases, as does the burden of coordinating care. In a traditional primary care setting, the capability to coordinate complex care may be lacking, leading to preventable hospitalizations.

An intuitive approach to caring for these vulnerable patients is to broaden the scope, increase the intensity, and improve the coordination of outpatient care, in the hope that this will lead to reduced hospital use and lower costs. ${ }^{7,8}$ Increased access to primary care is associated with decreased rates of hospitalizations for certain conditions, ${ }^{9,} 10$ and discontinuity of primary care is associated with increased risk of hospitalization. ${ }^{11}$ Outpatient care redesign efforts include patient-centered medical homes $(\mathrm{PCMH}),{ }^{12,} 13$ hospital-based care transition programs, ${ }^{14,15}$ and external case management. ${ }^{16,17}$ However, the effects of such efforts on utilization and clinical outcomes have been inconsistent. ${ }^{18-23}$

An alternative approach is intensive primary care (IPC), also referred to as ambulatory intensive care. ${ }^{7,} 24$ In such programs, patients at high risk for hospitalization or death are enrolled in a separate program (that may be within an existing primary care setting) that addresses a spectrum of medical and social needs, and coordinates care across settings. While PCMH and IPC both use interdisciplinary teams, IPC programs differ in that they specifically target populations at high risk of hospitalization, and provide a higher intensity of 
care and a broader range of services. IPC programs vary substantially in structure, function, and site of care, but the impact of these different approaches on hospitalization or mortality is unknown.

The objective of this work was to classify interdisciplinary, multicomponent IPC programs according to program characteristics, ${ }^{25}$ and to evaluate the effectiveness of these programs in reducing hospitalizations, emergency department (ED) visits, and mortality among patients at high risk for hospitalization or death.

\section{METHODS}

This review was initially requested for the Department of Veterans Affairs Patient Aligned Care Team (PACT) Health Delivery Committee to inform the creation of an IPC program. ${ }^{26}$

\section{Data Sources and Searches}

We searched for systematic reviews, controlled clinical trials, and observational studies in PubMed (1946 through 3/01/ 2017), CINAHL (1981 through 3/01/2017), the Cochrane Central Register of Controlled Trials (first quarter 2017), and the Cochrane Database of Reviews of Effects (first quarter 2017) using standard search terms for high utilizing complex patients, IPC, and hospital use. Additional citations were identified from reference lists, hand searching, and consultation with content experts. We limited the search to articles involving human subjects and available in the English language.

\section{Study Selection}

A description of study selection criteria is presented in Table 1. Two investigators reviewed titles, abstracts, and full text articles. One reviewer had methodological expertise, and the other had clinical content expertise. There was a high level of agreement, and all disagreements were resolved by consensus.

Table 1 Study Selection Criteria

\begin{tabular}{ll}
\hline \hline Population: & $\begin{array}{l}\text { Patients identified as high risk for hospital } \\
\text { admission and/or death }\end{array}$ \\
\hline Intervention: & $\begin{array}{l}\text { Multicomponent, interdisciplinary intensive primary } \\
\text { care programs (primary care defined as longitudinal, } \\
\text { continuous, and whole person-focused care }\end{array}$ \\
Comparator: & $\begin{array}{l}\text { Usual care } \\
\text { Outcomes: } \\
\text { department use, and hospital days }\end{array}$ \\
Timing: & $\begin{array}{l}\text { Studies that include a follow-up period of more than } \\
\text { 30 days }\end{array}$ \\
Setting: & $\begin{array}{l}\text { Ambulatory setting } \\
\text { Systematic reviews, controlled clinical trials, } \\
\text { observational studies }\end{array}$ \\
\hline design: &
\end{tabular}

\section{Data Extraction and Quality Assessment}

We abstracted data from all included studies on population, intervention, comparator, and timing characteristics and results for each included outcome. All data abstraction and internal validity ratings were first completed by one reviewer and then checked by another. All disagreements were resolved using consensus.

We used predefined criteria to rate the internal validity of all individual studies. Risk of bias in controlled clinical trials was assessed using the Cochrane Collaboration's tool and was judged as low, unclear, or high. ${ }^{28}$ We rated the internal validity (quality) of controlled observational studies as good, fair, or poor, using methods developed by the Drug Effectiveness Review Project (DERP) and based on the adequacy of the patient selection process, completeness of follow-up, adequacy of outcome ascertainment, use of acceptable statistical techniques to minimize potential confounding factors, and whether the duration of follow-up was reasonable to capture investigated events. Ratings of low risk of bias and good quality indicate high confidence in study findings. Ratings of unclear risk of bias and fair quality indicate the presence of plausible bias or some flaws that raise some doubt about study findings. Ratings of high risk of bias and poor quality indicate the presence of plausible bias or serious flaws that seriously weaken our confidence in study findings. ${ }^{29} \mathrm{We}$ graded strength of a body of evidence based on the guidance established for the AHRQ Evidence-based Practice Centers program. ${ }^{30}$ This approach incorporates four key domains: risk of bias (includes study design and aggregate quality), consistency, directness, and precision of the evidence.

\section{Program Classification}

We classified programs as primary care replacement (homebased), primary care replacement (clinic-based), or primary care augmentation, and assessed the impact of outcomes separately for each category. We derived our approach primarily from a classification developed by Yee et al., ${ }^{25}$ which grouped programs based on similarities in patient selection methods, scope of provided services, and organization of service delivery. As themes emerged during the review, we considered alternative ways to classify programs, but found that these categories were the most effective and consistent with other literature. $^{7}$

\section{RESULTS}

The literature flow diagram (Fig. 1) summarizes the results of the search and study selection processes. Searches resulted in 4151 potentially relevant articles. Of these, we included 11 randomized controlled trials ${ }^{31-41}$ and seven observational studies. ${ }^{42-48}$

Tables 2 and 3 summarize the study and intervention characteristics. The majority of the studies involved mostly elderly, 


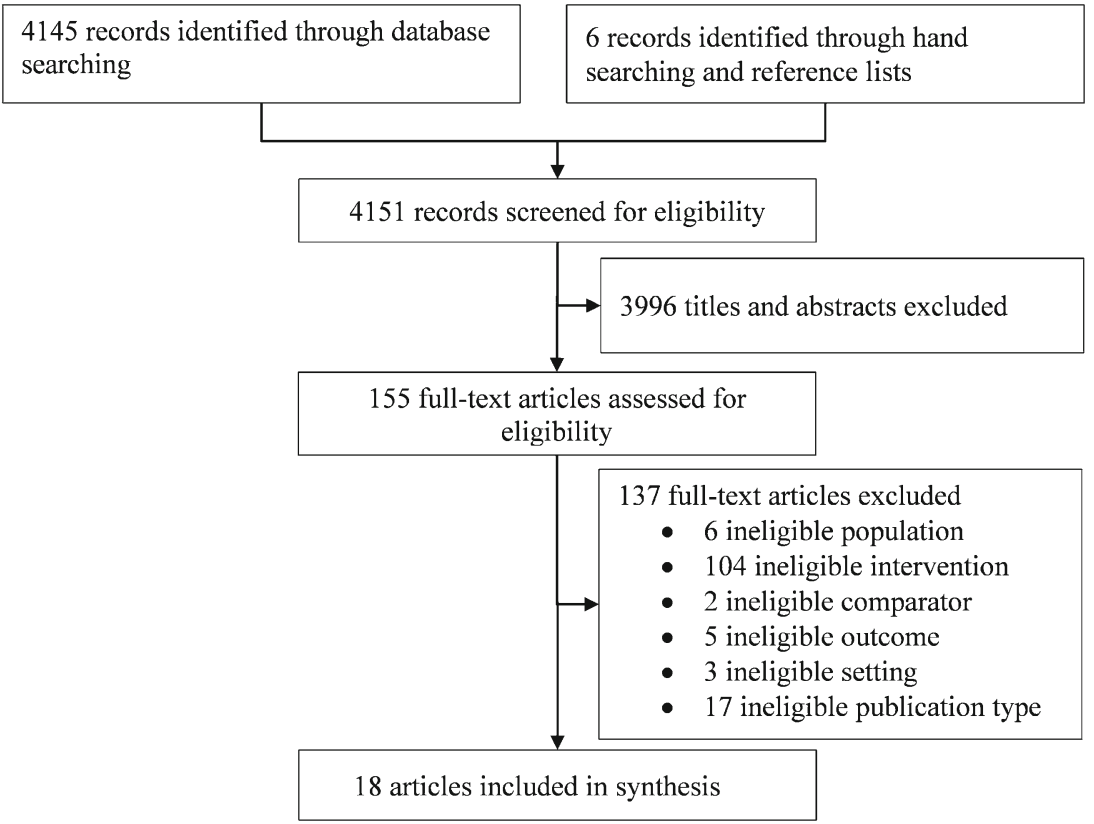

Figure 1 Study identification and selection.

non-white females, but four studies focused on veterans who were predominantly male. $^{36,37,45,48}$ Most studies were small $(N<300)$, and ranged in size from 59 to 3889 participants, with one observational study that included 364,972 participants. Follow-up duration ranged from 6 months to 4 years. Three studies selected patients based on high utilization of inpatient or emergency department services. ${ }^{39,} 44,47$ The remaining studies selected patients who were at least moderately disabled in activities of daily living $31,35-38,48,57$; homeless $^{46}$; aged $\geq 65,{ }^{31,33,34,48,58} \geq 67,{ }^{45} \geq 70,{ }^{32,35}$ or $\geq$ 75 years $^{42}$; had income below $200 \%$ of the federal poverty level $^{34,58}$; and/or who met nursing home eligibility criteria. ${ }^{43}$ Detailed patient selection criteria are described in Table 2.

Among the programs, five were home-based primary care replacement models (referred to as home-based care models), where a dedicated interdisciplinary primary care team delivered all needed services in patients' homes. $^{36-38,} 44$ Five were clinic-based primary care replacement models (referred to as clinic-based IPC), where patients transferred care from their regular primary care physicians to dedicated clinics that provided only high-intensity care, ${ }^{31,32,43,57}$ and eight used primary care augmentation, where additional highintensity services enhanced ongoing care from their regular primary care physician. ${ }^{33-35,39,42,58}$ Because of the clinical heterogeneity in design, patient population, interventions, and outcome assessment methods, we did not pool any data across studies.

Most studies were fair quality/unclear risk of bias or poor quality/high risk of bias. Common methodological limitations among RCTs were lack of blinding, unclear allocation concealment, and unclear methods for addressing incomplete outcome data. Among observational studies, common methodological limitations were lack of unbiased patient selection and lack of control for potential confounding variables. Study results are summarized in Table 4.

\section{Home-Based Models}

There is limited evidence that home-based care models reduce hospital utilization. VA HBPC enrollment was associated with fewer ACSC hospitalizations over 3-4 years in a recent national VA cohort study of 364,972 elderly veterans with diabetes (Table 2). ${ }^{45}$ VA HBPC enrollment did not reduce hospitalization in two earlier studies, but this may be due to their smaller sample sizes ( $N=233$ to 1966), shorter follow-up (612 months), or changes in HBPC over time. ${ }^{36,37}$ Other homebased programs implemented by single centers in Barcelona and Stockholm had mixed findings regarding hospital utilization, but our confidence in these findings is very low due to their serious limitations. ${ }^{38,44}$ For example, it is possible that the reduced hospital utilization in Hospital de Barcelona's home care program was exaggerated, because the urban setting characteristic of this home care program is typically associated with higher health care utilization than the rural setting of the control group. ${ }^{59}$ Similarly, in Stockholm's in-home hospital care program, the reduction in long-stay hospital utilization at 6 months may have been exaggerated, because participants in the home care group had a higher number of medical diagnoses than the control group (4.5 vs. $3.9 ; P=0.003$ ).

\section{Clinic-Based Intensive Primary Care}

The SIPA (French acronym for System of Integrated Care for Older Persons) ${ }^{31,57}$ in Montreal and the PACE (Program of All-Inclusive Care for the Elderly) in the U.S. ${ }^{43}$ were both associated with reduced hospital utilization at 19 to 
Table 2 Study and Intervention Characteristics (Stratified by Program Type)

\begin{tabular}{|c|c|c|c|c|c|c|c|}
\hline $\begin{array}{l}\text { Author, year } \\
\text { Study name }\end{array}$ & $\begin{array}{l}\text { Study } \\
\text { design }\end{array}$ & Setting & $\begin{array}{l}\text { Sample } \\
\text { size }\end{array}$ & $\begin{array}{l}\text { Follow- } \\
\text { up }\end{array}$ & Patient selection criteria & Usual care comparison & $\begin{array}{l}\text { Validity } \\
\text { assessment }\end{array}$ \\
\hline \multicolumn{8}{|l|}{ Home-based } \\
\hline $\begin{array}{l}\text { Edwards } \\
\text { et al., } 2017 \\
\text { VA HBPC }\end{array}$ & OBS & VA, nationwide & 364,972 & $\begin{array}{l}3-4 \\
\text { years }\end{array}$ & $\begin{array}{l}\text { Veterans aged } \geq 67 \text { with } \\
\text { diabetes mellitus, national } \\
\text { HBPC enrollment } \\
\text { guidelines } 49\end{array}$ & Not described & $\begin{array}{l}\text { Probably } \\
\text { valid }\end{array}$ \\
\hline $\begin{array}{l}\text { Hughes } \\
\text { et al., } 1990 \\
\text { VA HBPC }\end{array}$ & $\mathrm{RCT}$ & $\begin{array}{l}\text { Hines VA } \\
\text { Hospital, Illinois }\end{array}$ & 233 & $\begin{array}{l}6 \\
\text { months }\end{array}$ & $\begin{array}{l}\text { Recent hospitalization, } \\
\text { severely disabled } \\
(\geq 2 \text { ADL impairments) }\end{array}$ & $\begin{array}{l}\text { Customary care, } \\
\text { including use of } \\
\text { Medicare or other } \\
\text { community home care }\end{array}$ & Not valid \\
\hline $\begin{array}{l}\text { Hughes } \\
\text { et al., } 2000 \\
\text { VA HBPC }\end{array}$ & RCT & $\begin{array}{l}16 \text { VA medical } \\
\text { centers }\end{array}$ & 1966 & $\begin{array}{l}12 \\
\text { months }\end{array}$ & $\begin{array}{l}\text { Hospitalized within } 3 \\
\text { months, } 2 \text { or more ADL } \\
\text { impairments or a prognosis } \\
\text { of terminal illness, or } \\
\text { homebound with a primary } \\
\text { diagnosis of congestive } \\
\text { heart failure (CHF) or } \\
\text { chronic obstructive pulmo- } \\
\text { nary disease (COPD) }\end{array}$ & $\begin{array}{l}\text { Access to any VA- } \\
\text { sponsored services, ex- } \\
\text { cept HBPC and non-VA } \\
\text { post-acute services }\end{array}$ & $\begin{array}{l}\text { Possibly } \\
\text { valid }\end{array}$ \\
\hline $\begin{array}{l}\text { Melin, } \\
1995^{38}\end{array}$ & $\mathrm{RCT}$ & $\begin{array}{l}\text { County general } \\
\text { hospital and } \\
\text { primary care } \\
\text { center, Stockholm, } \\
\text { Sweden }\end{array}$ & 249 & $\begin{array}{l}6 \\
\text { months }\end{array}$ & $\begin{array}{l}\text { Hospitalized, "chronically } \\
\text { ill," dependent in } \geq 1 \text { Katz } \\
\text { ADL }\end{array}$ & $\begin{array}{l}\text { Continued treatment in } \\
\text { an acute or long-stay } \\
\text { hospital, followed by } \\
\text { standard district nurse } \\
\text { administered care at } \\
\text { home }\end{array}$ & Not valid \\
\hline $\begin{array}{l}\text { Vila et al., } \\
2015^{44}\end{array}$ & OBS & $\begin{array}{l}\text { Hospital de } \\
\text { Barcelona, Spain }\end{array}$ & 261 & $\begin{array}{l}203 \\
\text { days } \\
\text { (mean) }\end{array}$ & $\begin{array}{l}\text { Adults with one or more } \\
\text { severe, progressive, chronic } \\
\text { conditions and limited } \\
\text { longevity, admitted to the } \\
\text { hospital at least twice in the } \\
\text { preceding year for } \geq 25 \text { days }\end{array}$ & Not described & Not valid \\
\hline \multicolumn{8}{|l|}{ Clinic-based } \\
\hline $\begin{array}{l}\text { Beland et al., } \\
2006 \\
\text { SIPA }^{31}\end{array}$ & RCT & $\begin{array}{l}\text { Public community } \\
\text { organizations }\end{array}$ & 1309 & $\begin{array}{l}19 \\
\text { months }\end{array}$ & $\begin{array}{l}\text { Age } \geq 65 \text { years, "Frail } \\
\text { elderly": moderate disability } \\
(<-10 \text { on SMAF score, } \\
\text { which includes ADL, IADL, } \\
\text { incontinence, mental status, } \\
\text { mobility })^{51}\end{array}$ & $\begin{array}{l}\text { Usual home care services } \\
\text { with limited } \\
\text { time/availability and no } \\
\text { case management }\end{array}$ & $\begin{array}{l}\text { Possibly } \\
\text { valid }\end{array}$ \\
\hline $\begin{array}{l}\text { Boult et al., } \\
2001 \\
\text { GEM }^{32}\end{array}$ & RCT & $\begin{array}{l}\text { Ambulatory clinic, } \\
\text { community } \\
\text { hospital }\end{array}$ & 568 & $\begin{array}{l}18 \\
\text { months }\end{array}$ & $\begin{array}{l}\text { Medicare beneficiaries, age } \geq \\
70, \text { with a probability of } \\
\text { repeated admission of } 0.4 \text { or } \\
\text { higher using survey based } \\
\text { risk score }\end{array}$ & $\begin{array}{l}\text { Usual care with } \\
\text { primary care physician }\end{array}$ & $\begin{array}{l}\text { Possibly } \\
\text { valid }\end{array}$ \\
\hline $\begin{array}{l}\text { Ekdahl et al., } \\
2015^{41}\end{array}$ & RCT & $\begin{array}{l}\text { Ambulatory } \\
\text { geriatric unit, } \\
\text { Sweden }\end{array}$ & 252 & $\begin{array}{l}24 \\
\text { months }\end{array}$ & $\begin{array}{l}\text { Age } \geq 75, \text { hospitalized } \geq 3 \\
\text { times in previous year and } \\
\text { had } \geq 3 \text { medical diagnoses }\end{array}$ & $\begin{array}{l}\text { Usual health and social } \\
\text { care with primary care } \\
\text { centers, outpatient } \\
\text { hospital care, and social } \\
\text { care }\end{array}$ & $\begin{array}{l}\text { Probably } \\
\text { valid }\end{array}$ \\
\hline $\begin{array}{l}\text { Meret- } \\
\text { Hanke, } 2011 \\
\text { PACE }\end{array}$ & OBS & $\begin{array}{l}\text { Variety of U.S. } \\
\text { urban and rural } \\
\text { settings }\end{array}$ & 3889 & 2 years & $\begin{array}{l}\text { Age } \geq 55 \text {, nursing home- } \\
\text { eligible, typically dual } \\
\text { Medicare/Medicaid-eligible }\end{array}$ & Not described & $\begin{array}{l}\text { Possibly } \\
\text { valid }\end{array}$ \\
\hline $\begin{array}{l}\quad \text { O'Toole } \\
\text { et al., } 2016^{46} \\
\text { H-PACT } \\
\text { Primary care au }\end{array}$ & mentation & $\begin{array}{l}\text { National VA H- } \\
\text { PACT program }\end{array}$ & 3543 & $\begin{array}{l}12 \\
\text { months }\end{array}$ & Homeless veterans & Not described & Not valid \\
\hline $\begin{array}{l}\text { Coleman } \\
\text { et al., } 1999 \\
\text { Chronic Care } \\
\text { Clinic }^{33}\end{array}$ & RCT & $\begin{array}{l}\text { Ambulatory clinic } \\
\text { in a large staff- } \\
\text { model HMO }\end{array}$ & 169 & $\begin{array}{l}24 \\
\text { months }\end{array}$ & $\begin{array}{l}\text { Age } \geq 65, \text { highest risk of } \\
\text { hospitalization or functional } \\
\text { decline based on risk }^{53} \text { (included age, } \\
\text { score } \\
\text { gender, recent utilization, } \\
\text { chronic disease score based } \\
\text { on medication use) }\end{array}$ & Not described & Not valid \\
\hline $\begin{array}{l}\text { Counsell } \\
\text { et al., } 2007 \\
\text { GRACE }^{34}\end{array}$ & $\mathrm{RCT}$ & $\begin{array}{l}\text { Six community- } \\
\text { based health cen- } \\
\text { ters, Indianapolis, } \\
\text { Indiana }\end{array}$ & 951 & $\begin{array}{l}24 \\
\text { months }\end{array}$ & $\begin{array}{l}\text { Age } \geq 65, \text { recent primary } \\
\text { care visit, income }<200 \% \text { of } \\
\text { federal poverty level }\end{array}$ & $\begin{array}{l}\text { Access to all existing } \\
\text { primary and specialty } \\
\text { care services }\end{array}$ & $\begin{array}{l}\text { Possibly } \\
\text { valid }\end{array}$ \\
\hline $\begin{array}{l}\text { Fairhall } \\
\text { et al., } 2015 \\
\text { FIT }^{35}\end{array}$ & RCT & $\begin{array}{l}\text { Community-based } \\
\text { intervention, } \\
\text { Sydney, Australia }\end{array}$ & 241 & $\begin{array}{l}12 \\
\text { months }\end{array}$ & $\begin{array}{l}\text { Age } \geq 70, \text { score of } \geq 3 \text { on } \\
\text { Fried frailty criteria, }{ }^{55} \text { life } \\
\text { expectancy of }>12 \text { months, } \\
\text { no severe cognitive } \\
\text { impairment }\end{array}$ & $\begin{array}{l}\text { Usual care provided to } \\
\text { older residents from } \\
\text { community services and } \\
\text { their general practitioner }\end{array}$ & $\begin{array}{l}\text { Probably } \\
\text { valid }\end{array}$ \\
\hline
\end{tabular}


Table 2. (continued)

\begin{tabular}{|c|c|c|c|c|c|c|c|}
\hline $\begin{array}{l}\text { Author, year } \\
\text { Study name }\end{array}$ & $\begin{array}{l}\text { Study } \\
\text { design }\end{array}$ & Setting & $\begin{array}{l}\text { Sample } \\
\text { size }\end{array}$ & $\begin{array}{l}\text { Follow- } \\
\text { up }\end{array}$ & Patient selection criteria & Usual care comparison & $\begin{array}{l}\text { Validity } \\
\text { assessment }\end{array}$ \\
\hline $\begin{array}{l}\text { Jiwa et al., } \\
2002^{42}\end{array}$ & OBS & $\begin{array}{l}\text { Single general } \\
\text { practitioner } \\
\text { practice, UK }\end{array}$ & 59 & $\begin{array}{l}6 \\
\text { months }\end{array}$ & $\begin{array}{l}\text { Age } \geq 75 \text { years, Clinician } \\
\text { judgment of patients at risk } \\
\text { of hospital admission based } \\
\text { on frailty, multiple diagnoses, } \\
\text { polypharmacy, or poor social } \\
\text { support }\end{array}$ & Not described & Not valid \\
\hline $\begin{array}{l}\text { Ritchie et al., } \\
2016\end{array}$ & OBS & $\begin{array}{l}\text { Academic medical } \\
\text { center, UCSF }\end{array}$ & 148 & $\begin{array}{l}\geq 6 \\
\text { months }\end{array}$ & $\begin{array}{l}\geq 5 \text { ED visits or } \geq 2 \text { inpatient } \\
\text { hospitalization in past } 12 \\
\text { months }\end{array}$ & Not described & Not valid \\
\hline \multicolumn{8}{|l|}{$\begin{array}{l}\text { GRACE/Care } \\
\text { Support } 47\end{array}$} \\
\hline $\begin{array}{l}\text { Schubert } \\
\text { et al., } 2016 \\
\text { GRACE }^{48}\end{array}$ & OBS & $\begin{array}{l}\text { Indianapolis VA } \\
\text { Medical Center }\end{array}$ & 256 & $\begin{array}{l}12 \\
\text { months }\end{array}$ & $\begin{array}{l}\text { Age } \geq 65 \text {, life expectancy }>6 \\
\text { months, clinician } \\
\text { judgment with focus on } \\
\text { geriatric syndromes } \\
\text { (delirium, cognitive } \\
\text { impairment, frailty, } \\
\text { multimorbidity, } \\
\text { polypharmacy, falls) }\end{array}$ & Geriatric care clinic & $\begin{array}{l}\text { Possibly } \\
\text { valid }\end{array}$ \\
\hline $\begin{array}{l}\text { Sledge et al., } \\
2006 \\
\text { PIC }^{39}\end{array}$ & RCT & $\begin{array}{l}\text { Primary care } \\
\text { center in } \\
\text { northeastern U.S. }\end{array}$ & 96 & $\begin{array}{l}12 \\
\text { months }\end{array}$ & $\begin{array}{l}\geq 2 \text { Medical or surgical } \\
\text { hospital admissions in prior } \\
12 \text { months. Patients with } \\
\text { costs }>2 \text { SD of log- } \\
\text { transformed mean or Charl- } \\
\text { son Comorbidity Index of } \\
\geq 5 \text { excluded }\end{array}$ & $\begin{array}{l}\text { Usual care directed by } \\
\text { PCP; on-site psychiatric } \\
\text { consultation available by } \\
\text { PCP referral }\end{array}$ & Not valid \\
\hline $\begin{array}{l}\text { Zulman } \\
\text { et al., } 2017 \\
\text { ImPACT }^{40}\end{array}$ & $\mathrm{RCT}$ & VA Palo Alto & 583 & $\begin{array}{l}16 \\
\text { months }\end{array}$ & $\begin{array}{l}\text { Health care costs or risk for } \\
\text { hospitalization in top } 5 \% \text { of } \\
\text { facility (calculated using } \\
\text { risk score) }\end{array}$ & Not described & $\begin{array}{l}\text { Probably } \\
\text { valid }\end{array}$ \\
\hline
\end{tabular}

Abbreviations: $O B S=$ observational; SIPA $=$ System of Integrated Care for Older Persons, HBPC = home-based primary care; PACE $=$ Program of AllInclusive Care for the Elderly; GRACE = Geriatric Resources for Assessment and Care of Elders; PIC = primary intensive care; $P C P=$ primary care physician; FIT = Frailty Intervention Trial; GEM = geriatric evaluation and management; ED = emergency department; H-PACT = Homeless Patient Aligned Care Team; UCSF = University of California San Francisco; ImPACT = Intensive Management Patient Aligned Care Team; SMAF = Systeme de mesure de l'autonomie fonctionelle; $R C T=$ Randomized Controlled Trial; $A D L=$ activities of daily living; $I A D L=$ instrumental activities of daily living *We converted DERP and Cochrane risk of bias (ROB) ratings to validity assessments as follows: ROB "Low" or DERP Good"- $\rightarrow$ "Probably valid"; $R O B$ "High" or DERP "Poor"- $\rightarrow$ "Not valid"; ROB "Unclear" or DERP "Fair" $\rightarrow$ "Possibly valid"

24 months. ${ }^{31,43,57}$ Additionally, PACE demonstrated reduced risk of mortality in the first 18 months compared to usual care, but it increased between months 18 and 24. Both focused on assisting frail elderly individuals with functional limitations. The main methodological limitation of these studies was possible attrition bias. For example, in the PACE study, there were five times as many exclusions from the intervention group due to incomplete data.

Geriatric evaluation and management (GEM), ambulatory geriatric units (AGe-FIT), and Homeless PACT (H-PACT) were generally not associated with significant reductions in mortality or hospital utilization over a period of 12 25 months. $^{32,}$ 41, 46 The exception was AGe-FIT, which reduced the mean number of inpatient days over 24 months (11.5 vs. $15.2, p=0.035$ ) in 382 elderly individuals in Sweden who had been hospitalized at least three times during the past year. ${ }^{41}$ Among these models, H-PACT is unique in that it focuses on homeless individuals at high risk of hospitalization and offers a separate high-intensity primary care clinic that includes resources such as improved walk-in capacity, colocated mental health, housing, hygiene, clothing, and food vouchers, and intensive case management. While a 6-month pre-post assessment of utilization demonstrated a $19 \%$ decrease in ED visits and a $34.7 \%$ reduction in hospitalizations, there was no control group, no statistical test of significance, and no attempt to control for pre-existing trend or regression to the mean. ${ }^{43}$

\section{Primary Care Augmentation}

Three studies using the Geriatric Resources for Assessment and Care of Elders (GRACE) model ${ }^{34,47,48,58}$ demonstrated reductions in hospitalization rates and/or emergency room visits. A GRACE randomized trial was performed among 951 low-income seniors across six community-based health centers in Indianapolis, Indiana. ${ }^{34,58}$ The trial's main methodological limitation was that it compared groups of physicians who served different patient populations, as evidenced by the significantly lower rate of county medical assistance use in the GRACE intervention group at baseline (83.7\% vs. $89.0 \% ; P=0.02)$. GRACE's impact on hospital utilization was limited to a subgroup of 226 patients with the highest risk of baseline hospitalization (Probability of Repeated Admission score of 0.4 or higher), and only in the second year. Also, as baseline characteristics were not provided for the high-risk subgroup, we could not rule out that potential differences in patient characteristics may have mediated the positive effect of the GRACE intervention on outcomes. In a study of GRACE 
Table 3 Intervention Characteristics (Stratified by Program Type)

\begin{tabular}{|c|c|}
\hline Program & Key process elements \\
\hline \multicolumn{2}{|l|}{ Home-based } \\
\hline Edwards et al., & Hospital-based home care (HBHC) to "heavy care" patients (terminally ill and severely disabled), \\
\hline $2017^{45}-1$ & alternative to nursing home. Management inside and outside of hospital; integrated networks; 24 -h contact; \\
\hline $1990^{36}$ & \\
\hline \multirow{2}{*}{\multicolumn{2}{|c|}{$\begin{array}{l}\text { Hughes et al., } \\
2000^{39}\end{array}$}} \\
\hline & \\
\hline \multicolumn{2}{|l|}{ VA HBPC/HBHC } \\
\hline Melin, $1995^{38}$ & $\begin{array}{l}\text { In-home hospital care as alternative to in-hospital care prompted by bed availability crisis; patients at risk of } \\
\text { long-stay care; rehab on a round-the-clock basis }\end{array}$ \\
\hline Vila et al., $2015^{44}$ & $\begin{array}{l}\text { Home health care; continued proactive monitoring for early detection and treatment of disease exacerbation: } \\
\text { direct telephone available } 12 \mathrm{~h} \text { a day; rapid }(\leq 6 \mathrm{~h} \text { ) mobilization of intensive hospital home care } \\
\text { (IV drug therapy, oxygen therapy, comprehensive assessment within } 24 \mathrm{~h} \text { of discharge) }\end{array}$ \\
\hline \multicolumn{2}{|r|}{ 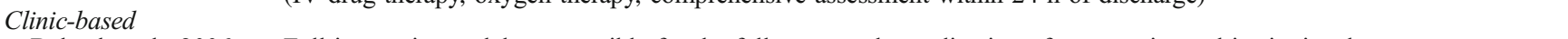 } \\
\hline Beland et al., 2006 & Full integration: solely responsible for the full range and coordination of community and institutional \\
\hline $\mathrm{SIPA}^{31}$ & $\begin{array}{l}\text { (acute and long-term) health and social services. Rapid mobilization of resources through } 24 \text {-h on-call } \\
\text { service and intensive home care }\end{array}$ \\
\hline Boult et al., 2001 & Geriatrician, gerontological nurse practitioner (GNP), nurse, and social worker team-led primary care, \\
\hline $\mathrm{GEM}^{32}$ & $\begin{array}{l}\text { including comprehensive assessment, } 24 \text {-h-a-day on-call services, monthly clinic visits with free transportation, } \\
\text { regular telephone calls between visits to monitor and coordinate care }\end{array}$ \\
\hline Ekdahl et al., $2015^{41}$ & Ambulatory geriatric unit with nurse, geriatrician/resident physician, municipal care manager, occupational therapist, \\
\hline AGe-FIT & physiotherapist, dietician, and administrative assistant \\
\hline Meret-Hanke, 2011 & Full integration of financing and delivery of acute and long-term care services for nursing home-eligible patients; \\
\hline $\mathrm{PACE}^{43}$ & management of care across all settings; regular clinical monitoring; capitated funding allows more flexibility \\
\hline O'Toole et al., & Low-threshold access to care with walk-in capacity and clinical outreach to homeless people, integrated \\
\hline $2016^{46}$ & primary care and mental health services, intensive health care management, and staff training in homeless care skills \\
\hline \multicolumn{2}{|c|}{ Primary care augmentation } \\
\hline Coleman et al., 1999 & Scheduled half-day multidisciplinary visits every $3-4$ months; physician and nurse education \\
\hline Chronic Care & \\
\hline \multicolumn{2}{|l|}{ Clinic $^{33}$} \\
\hline Counsell et al., & Integration of the geriatrics team within the primary care environment; in-home assessment and care management \\
\hline $2007^{34}$ & provided by a social worker and nurse practitioner team; extensive use of specific care protocols; utilization of an \\
\hline Ritchie et al., & integrated electronic medical record and a Web-based care management tracking tool; and integration with affiliated \\
\hline $2016^{47}$ & pharmacy, mental health, home health, community-based, and inpatient geriatric care services; monthly proactive phone \\
\hline GRACE & follow-ups; dedicated phone line; coordination of care between providers \\
\hline $\begin{array}{l}\text { Fairhall et al., } 2015 \\
\text { FIT }^{35}\end{array}$ & $\begin{array}{l}\text { Case management; targeting domains of frailty—focus on exercise and nutritional supplementation; case conferences; } \\
\text { staff experienced in aged care }\end{array}$ \\
\hline Jiwa et al., $2002^{42}$ & $\begin{array}{l}\text { Proactive outreach (regular visits, phone calls), emphasis on care at home and self-management with support of } \\
\text { community teams }\end{array}$ \\
\hline $\begin{array}{l}\text { Sledge et al., } 2006 \\
\text { PIC }^{39}\end{array}$ & $\begin{array}{l}\text { Comprehensive assessment and follow-up care management with strong mental health component; eligibility based } \\
\text { on recent hospitalizations, rather than frailty as in all other studies; minimum follow-up was monthly telephone call and } \\
\text { phone/pager availability } 5 \text { days a week-more as needed }\end{array}$ \\
\hline $\begin{array}{l}\text { Zulman et al., } 2017 \\
\text { ImPACT }^{40}\end{array}$ & $\begin{array}{l}\text { Multidisciplinary team (nurse practitioner, physician, social worker, recreational therapist) partnered with patients' medical } \\
\text { home, comprehensive patient assessment and tracking, care management of medical and social service needs, frequent } \\
\text { contact, and coordination of care with VA and non-VA clinicians }\end{array}$ \\
\hline
\end{tabular}

in a VA Medical Center in Marion County, Indiana, the new model was implemented in four clinics, while one clinic that declined to participate served as a control group. Utilization was compared in the 12 months prior to and after implementation, in both GRACE and control groups, using a differencein-differences approach. There were no significant differences in 30-day readmission or hospital admission, but there was a significant decrease in inpatient days associated with GRACE $(-221.4$ annual bed days/100 veterans, $p=0.01) .{ }^{47}$ In a second study, GRACE was adapted to an academic medical center in San Francisco, and named Care Support. Comparison of utilization in the 6 months pre- and post-Care Support enrollment demonstrated a decline in the mean number of ED visits $(5.5$ to $0, p=0.015$ ) and hospitalizations (5.5 to $0, p<0.001)$. This study included no comparison group, and no method to control for regression to the mean or pre-existing trend. ${ }^{47}$

None of the other primary care augmentation interventions succeeded in reducing mortality or hospital utilization outcomes. Among the remaining studies, ImPACT is the largest, most recent, and highest-quality randomized controlled trial. In ImPACT, patients were identified as the 5\% highest-cost patients or those with the $5 \%$ highest risk of hospitalization using a risk prediction algorithm. A multidisciplinary team consisting of a nurse practitioner, physician, social worker, and recreational therapist performed a comprehensive patient assessment, provided care management for medical and social service needs, and coordinated care with VA and non-VA providers. Notably, in ImPACT, both the control group and the intervention group saw reductions in acute and extended care utilization and cost of care, and there was no significant difference between groups.

\section{DISCUSSION}

In this review, we identified 18 studies of IPC interventions and categorized them into three major types: home-based 
Table 4 Summary of Results (Stratified by Program Type, Intervention vs. Control)

\begin{tabular}{|c|c|c|c|c|}
\hline $\begin{array}{l}\text { Author, year } \\
\text { Study name }\end{array}$ & Mortality rate & Hospital admission/readmission & Hospital days & Emergency department visits \\
\hline $\begin{array}{l}\text { Home-based } \\
\text { Edwards } \\
\text { et al., } 2017 \\
\text { VA HBPC }\end{array}$ & NR & $\begin{array}{l}\text { ACSC hospitalization } \mathrm{OR}=0.35 \\
(95 \% \text { CI, } 0.30 \text { to } 0.42)\end{array}$ & NR & NR \\
\hline $\begin{array}{l}\text { Hughes et al., } \\
1990 \\
\text { VA HBPC }\end{array}$ & 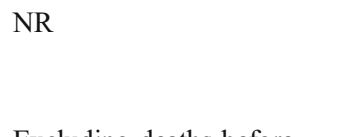 & 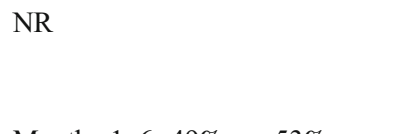 & $\begin{array}{l}13.68 \text { vs. } 13.53 \\
(P=\text { NS**) } \\
\text { Non-VA hospital days: } \\
2.11 \text { vs. } 0.82(P=0.10)\end{array}$ & $\begin{array}{l}\text { VA ER visits: } 0.76 \text { vs. } 0.61 \\
(P=\text { NS**) } \\
\text { Non-VA ER visits: } 0.11 \text { vs. } \\
0.10\left(P=\mathrm{NS}^{* *}\right)\end{array}$ \\
\hline $\begin{array}{l}\text { Hughes et al., } \\
2000 \\
\text { VA HBPC }^{37}\end{array}$ & $\begin{array}{l}\text { Excluding deaths before } \\
\text { discharge: } 34.7 \% \text { vs. } 34.1 \% \\
(P=0.08) \\
\text { Including deaths before } \\
\text { discharge: } 38 \% \text { vs. } 37 \% \\
(P \text { NR })\end{array}$ & $\begin{array}{l}\text { Months } 1-6: 49 \% \text { vs. } 53 \% \\
(P=0.07) \\
\text { Months } 1-12: 61 \% \text { vs. } 63 \% \\
(P=0.35)\end{array}$ & $\begin{array}{l}\text { Months } 1-6: 9.3 \text { vs. } 9.5 \\
(P=0.16) \\
\text { Months } 1-12: 14.7 \text { vs. } \\
13.3(P=0.95)\end{array}$ & NR \\
\hline $\begin{array}{l}\text { Melin, } \\
1995^{38}\end{array}$ & $26 \%$ vs. $27 \%(P$ NR $)$ & NR & $\begin{array}{l}\text { Survivors }(N=183) \\
\text { Short-term (days): } 24 \text { vs. } \\
25(P=0.50) \\
\text { Long-term (days): } 16 \text { vs. } \\
49(P<0.001) \\
\text { Rehab hosp. (days): } 2 \text { vs. } \\
3(P=0.87) \\
\text { Decedents }(N=66) \\
\text { Short-term (days): } 149.9 \\
\text { vs. } 179.9(P=0.93) \\
\text { Long-term (days): } 7.4 \text { vs. } \\
53.6(P=0.18) \\
\text { Rehab hosp. }(\text { days }): 5.4 \\
\text { vs. NR (P NR) }\end{array}$ & NR \\
\hline $\begin{array}{l}\text { Vila et al., } \\
2015^{44} \\
\text { Clinic-based }\end{array}$ & $40 \%$ vs. $56 \%(P \mathrm{NR})$ & 0.19 vs. $0.39(P=0.02)$ & 1 vs. $3.2(P<0.001)$ & 0.3 vs. $0.2\left(P=\mathrm{NS}^{* *}\right)$ \\
\hline $\begin{array}{l}\text { Beland et al., } \\
2006 \\
\text { SIPA }^{31}\end{array}$ & 19 vs. $22 \%$ & $\begin{array}{l}\mathrm{OR}=0.52 \\
(95 \% \mathrm{CI}, 0.33 \text { to } 0.82)\end{array}$ & $\begin{array}{l}\mathrm{OR}=0.93 \\
(95 \% \text { CI, } 0.71 \text { to } 1.18)\end{array}$ & $\begin{array}{l}\mathrm{OR}=0.92 \\
(95 \% \text { CI, } 0.73 \text { to } 1.20)\end{array}$ \\
\hline $\begin{array}{l}\text { Boult et al., } \\
2001 \\
\text { GEM }^{32}\end{array}$ & $9.5 \%$ vs. $10.2 \%, P=0.88$ & NR & NR & NR \\
\hline $\begin{array}{l}\text { Ekdahl et al., } \\
2015^{41}\end{array}$ & $\begin{array}{l}18.8 \% \text { vs. } 27.0 \% \\
\mathrm{HR}=1.51 \\
(95 \% \text { CI, } 0.99 \text { to } 2.31)\end{array}$ & NR & NR & NR \\
\hline $\begin{array}{l}\text { Meret-Hanke, } \\
2011 \\
\text { PACE }^{43}\end{array}$ & $\begin{array}{l}\text { Difference (all } P<0.01) \\
\text { 1st } 6 \text { months: }-0.01 \\
\text { 2nd } 6 \text { months: }-0.02 \\
\text { 3rd } 6 \text { months: }-0.01 \\
\text { 4th } 6 \text { months: } 0.02\end{array}$ & $\mathrm{OR}=0.16(P=0.01)$ & $\begin{array}{l}\text { Weighted mean } \\
\text { difference: } \\
-0.54(P<0.01)\end{array}$ & D \\
\hline $\begin{array}{l}\text { O'Toole et al., } \\
2016 \\
\text { H-PACT }^{46}\end{array}$ & NR & $\begin{array}{l}\text { Pre-enrollment: } 812 \\
\text { hospitalizations } \\
\text { Post-enrollment: } 503 \\
\text { hospitalizations } \\
\text { ( } 34.7 \% \text { reduction) }\end{array}$ & NR & $\begin{array}{l}\text { Pre-enrollment: } 3022 \mathrm{ED} \text { visits } \\
\text { Post-enrollment: } 2447 \mathrm{ED} \\
\text { visits ( } 19.0 \% \text { reduction) }\end{array}$ \\
\hline $\begin{array}{l}\text { Primary care au } \\
\text { Coleman } \\
\text { et al., } 1999 \\
\text { Chronic Care } \\
\text { Clinic }^{33}\end{array}$ & $\begin{array}{l}\text { nentation } \\
16 \% \text { vs. } 17 \% ;(P=\mathrm{NS})^{* *}\end{array}$ & $36.5 \%$ vs. $34.3 \%(P=0.72)$ & 6.4 vs. $5.4(P=0.57)$ & 0.23 vs. $0.27(P=0.73)$ \\
\hline $\begin{array}{l}\text { Counsell } \\
\text { et al., } 2007 \\
\text { GRACE }^{34}\end{array}$ & $7.0 \%$ vs. $7.0 \%(P=0.64)$ & $\begin{array}{l}\text { Full sample: } 700 \text { vs. } 740 \\
(P=0.66) \\
\text { High-risk: } \\
\text { Year 1: } 705 \text { vs. } 798(P=0.60) \\
\text { Year 2: } 396 \text { vs. } 705(P=0.03) \\
\text { per 1000 }\end{array}$ & $\begin{array}{l}\text { Full sample: } 700 \text { vs. } 740 \\
(P=0.66) \\
\text { High-risk: } \\
\text { Year } 1: 705 \text { vs. } 798 \\
(P=0.60) \\
\text { Year } 2: 396 \text { vs. } 705 \\
(P=0.03) \\
\text { per } 1000\end{array}$ & $\begin{array}{l}\text { Full sample: } \\
\text { Year 1: } 823 \text { vs. } 937(P=0.22) \\
\text { Year 2: } 643 \text { vs. } 841(P=0.01) \\
\text { High-risk subgroup } \\
\text { Year 1: } 1098 \text { vs. } 1149 \\
(P=0.79) \\
\text { Year 2: } 848 \text { vs. } 1314 \\
(P=0.03)\end{array}$ \\
\hline $\begin{array}{l}\text { Fairhall et al., } \\
2015 \\
\text { FIT }^{35}\end{array}$ & 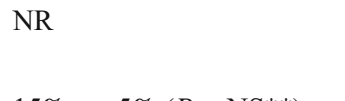 & $\begin{array}{l}\text { Average admissions per } \\
\text { participant:1.31 vs. } 1.14(P \mathrm{NR})\end{array}$ & $\begin{array}{l}15 \text { vs. } 14 \text { days/admission } \\
(P \text { NR })\end{array}$ & NR \\
\hline $\begin{array}{l}\text { Jiwa et al., } \\
2002^{42}\end{array}$ & $15 \%$ vs. $5 \%\left(P=\mathrm{NS}^{* *}\right)$ & 4 vs. $7(P=$ NS $* *)$ & NR & NR \\
\hline $\begin{array}{l}\text { Ritchie et al., } \\
2016 \\
\text { GRACE }^{47}\end{array}$ & NR & $\begin{array}{l}\text { Pre-enrollment: median of } 5.5 \\
\text { hospitalizations } \\
\text { Post-enrollment: median of } 0 \\
\text { hospitalizations }(P<0.001)\end{array}$ & NR & $\begin{array}{l}\text { Pre-enrollment: median of } 5.5 \\
\text { ED visits } \\
\text { Post-enrollment: median of } 0 \\
\text { ED visits }(P=0.015)\end{array}$ \\
\hline
\end{tabular}


Table 4. (continued)

\begin{tabular}{|c|c|c|c|c|}
\hline $\begin{array}{l}\text { Author, year } \\
\text { Study name }\end{array}$ & Mortality rate & Hospital admission/readmission & Hospital days & Emergency department visits \\
\hline $\begin{array}{l}\text { Schubert } \\
\text { et al., } 2016 \\
\text { GRACE }^{48}\end{array}$ & NR & $\begin{array}{l}\text { Annual admission: }-44.1 \\
(95 \% \mathrm{CI},-110.7 \text { to } 22.5)^{*} \\
30 \text {-day readmissions: }-13.1 \\
(95 \% \mathrm{CI},-36.4 \text { to } 10.2)^{*}\end{array}$ & $\begin{array}{l}-221.4 \\
(95 \% \mathrm{CI},-362.7 \text { to } \\
-80.1)^{*}\end{array}$ & $\begin{array}{l}-19.4 \\
(95 \% \mathrm{CI},-111.2 \text { to } 72.4)^{*}\end{array}$ \\
\hline $\begin{array}{l}\text { Sledge et al., } \\
2006 \\
\text { PIC }^{39}\end{array}$ & $6 \%$ vs. $10 \%(P$ NR $)$ & $\begin{array}{l}\text { Mean change: }-0.1 \text { vs. }-0.3 \\
(P=0.55)\end{array}$ & NR & $\begin{array}{l}\text { Mean change: }-0.52 \text { vs. }-0.6 \\
(P=0.9)\end{array}$ \\
\hline $\begin{array}{l}\text { Zulman et al., } \\
2017 \\
\operatorname{ImPACT}^{40}\end{array}$ & $\begin{array}{l}12.1 \% \text { vs. } 13.6 \%, \\
(1.4 \% \text { difference, } 95 \% \mathrm{CI} \text {, } \\
-5.7 \% \text { to } 7.3 \%)\end{array}$ & $\begin{array}{l}\text { Medicine/surgery ward: } 0.06^{*} \\
(P=\mathrm{NS} * *)\end{array}$ & $\begin{array}{l}\text { Medicine/surgery ward: } \\
-0.73^{*}\left(P=\mathrm{NS}^{* *}\right)\end{array}$ & $\begin{array}{l}-0.12^{*} \\
\left(P=\mathrm{NS}^{* *}\right)\end{array}$ \\
\hline
\end{tabular}

*Difference-in-differences; **numerical P-value not reported

Abbreviations: $N R=$ not reported; $N S=$ non-significant; SIPA = System of Integrated Care for Older Persons, HBPC = home-based primary care; $P A C E=$ Program of All-Inclusive Care for the Elderly; GRACE = Geriatric Resources for Assessment and Care of Elders; PIC = primary intensive care; FIT = Frailty Intervention Trial; GEM = geriatric evaluation and management; ED = emergency department; H-PACT = Homeless Patient Aligned Care Teams; ImPACT = Intensive Management Patient Aligned Care Team; ACSC = ambulatory care-sensitive conditions

programs, clinic-based IPC, and primary care augmentation programs. The programs varied in the way they identified and screened patients for enrollment, though most focused on older adults with functional limitations. Formalized care planning was present in all interventions, many relying upon the comprehensive geriatric assessment. All programs utilized multidisciplinary staff to meet a range of patient needs, and most commonly included physicians, nurses, social workers, physical therapists, mental health providers, and pharmacists. Some clinic-based IPC programs and primary care augmentation programs also included home visits. Overall, we found moderate- to low-strength evidence that some programs (VAHBPC, PACE, SIPA, and GRACE) were associated with fewer hospital admissions, but no evidence of impact on ED visits or mortality.

While there has been increasing interest in IPC ${ }^{60}$ relatively few studies met our inclusion criteria. Notably, many of the studies we did identify were older and were completed before recent changes in health care such as the widespread adoption of electronic health records. Additionally, several studies used weak study designs - for example, pre-post assessment of utilization without a control group. This design is susceptible to both temporal trends, such as decreasing hospitalization rates, ${ }^{61}$ and regression to the mean. In the ImPACT trial, reductions in utilization and cost were seen in both intervention and control patients, demonstrating the need for study designs that include control groups. ${ }^{40}$ Additionally, our review lacked some often-cited IPC interventions including the Camden Coalition or the AtlantiCare Special Care Center, ${ }^{62-64}$ as evaluations of these programs do not appear in the peerreviewed literature. This is likely because programs often do not include evaluations, and among those that do, evaluations are difficult to perform and may take years to complete. Future IPC interventions should include integrated evaluations with rigorous study designs, ideally including randomization.

The current evidence is not adequate to reach a conclusion as to what the right population is for IPC interventions. Patient selection criteria were not well described in many of the studies we reviewed, and no clear patterns of impact on outcomes emerged. Some programs used risk prediction algorithms that included prior diagnoses, laboratory values, and utilization. ${ }^{33,40}$ Others focused on specific subpopulations and selected patients based on older age, an inability to perform activities of daily living, or homelessness. One chose patients based purely on prior health care utilization. ${ }^{47} \mathrm{~A}$ potential strategy for new programs would be to identify their specific high-risk patients and assess their needs early in program design, to ensure that provided services fit population needs.

Most of the programs we reviewed used large multidisciplinary teams to deliver a range of specialized services and to coordinate the care of complex patients. However, for complex patients, adding more providers to their care may increase discontinuity with their primary provider and increase the burden of care coordination. Given the negative results of many of these studies, it is possible that attempts to manage complex care using large multidisciplinary teams may be ineffective for some high-needs patients, as the burden of coordination may outweigh the benefits of the specialized skills of each team member. An alternative approach would be to explicitly simplify care to minimize discontinuities and coordination burden by using fewer providers who have a wider scope of practice to care for patients in all settings, such as both in and out of the hospital. In such models, the role of "care coordinator" may be irrelevant. ${ }^{65}$

Among the studies reviewed, success in reducing hospitalization was achieved in some programs and not others, and success was context-dependent. We had hoped to identify key program features, such as patient selection criteria, that may have contributed to the success or failure of these programs. Unfortunately, reporting of key intervention characteristics was inconsistent, which is a common problem in complex multicomponent intervention studies. ${ }^{66}$ In addition, the data collected on intervention fidelity, implementation process, and contextual factors at individual intervention sites varied among studies. Future works could use both qualitative and quantitative methods to examine intervention fidelity, implementation, and context. ${ }^{67-69}$ Such data could provide insight into what makes IPC programs work, for whom, and why. ${ }^{70}$ The VA's PACT Intensive Management Program has 
incorporated many of these strategies in their implementation and evaluation of a multisite IPC program within PACT. ${ }^{71,72}$

Our work has several limitations. First, while we attempted to create a precise definition of IPC and differentiate it from other efforts to intensify ambulatory care for high-risk patients (such as care management), we found significant overlap in approaches, both between our identified care models and with other care intensification strategies. Additionally, the lack of a standard taxonomy made this topic difficult to search for. Although we attempted to use an exhaustive list of search terms, our search may have missed some relevant studies. Second, our criteria primarily identified geriatric care models focused on older adults with multiple chronic conditions and functional limitations. Fewer identified programs focused on other at-risk populations, and thus our review may have more limited generalizability. However, this highlights the fact that older adults with multiple chronic conditions and functional limitations are an at-risk population that may be an appropriate target for IPC interventions. Finally, some efforts by accountable care organizations to improve care coordination for complex patients spanned the fields of primary care, specialty care, hospital care, and post-acute care, combining features of the PCMH, transitional care programs, and IPC models. ${ }^{73}$ The principle underlying these approaches is that in order to achieve the triple aim of improving quality, reducing costs, and improving patient experience, one must go beyond innovations in primary care delivery. However, this review does not address such integrated approaches. IPC programs that had unimpressive results in our review might turn out to be valuable components of a more integrated approach. ${ }^{73}$

We identified studies representing each of three models of IPC: home-based models, clinic-based IPC, and primary care augmentation. Programs varied in their success in reducing hospitalizations. Future IPC interventions should include rigorous evaluations that include consistent and standardized reporting of intervention characteristics and that collect data on implementation and contextual factors, to further our understanding of what makes such programs successful.

Acknowledgements: We would like to thank the staff of the Evidencebased Synthesis Program Coordinating Center for their assistance.

Corresponding Author: Samuel T. Edwards, MD, MPH; Section of General Internal Medicine VA Portland Health Care System, Portland, OR, USA (e-mail: samuel.edwards@va.gov).

Funders: Funding was provided by the U.S. Department of Veterans Affairs, Veterans Health Administration, Office of Research and Development, Quality Enhancement Research Initiative. Dr. Chan is supported in part by grant number K12HSO22981 from the Agency for Healthcare Research and Quality.

\section{Compliance with Ethical Standards:}

Conflict of Interest: All authors declare that they have no conflict of interest.

Prior Presentations: None.

\section{REFERENCES}

1. Zulman DM, Pal Chee C, Wagner TH, et al. Multimorbidity and healthcare utilisation among high-cost patients in the US Veterans Affairs Health Care System. BMJ Open 2015;5(4):e007771.

2. Wolff JL, Starfield B, Anderson G. Prevalence, expenditures, and complications of multiple chronic conditions in the elderly. Arch Intern Med 2002; 162(20):2269-2276.

3. Prados-Torres A, Calderón-Larrañaga A, Hancco-Saavedra J, Poblador-Plou B, van den Akker M. Multimorbidity patterns: a systematic review. J Clin Epidemiol 2014;67(3):254-266.

4. Barnett K, Mercer SW, Norbury M, Watt G, Wyke S, Guthrie B. Epidemiology of multimorbidity and implications for health care, research, and medical education: a cross-sectional study. Lancet 2012;380(9836):37-43.

5. Greysen SR, Cenzer IS, Auerbach AD, Covinsky KE. Functional impairment and hospital readmission in Medicare seniors. JAMA Intern Med 2015;175(4):559-565.

6. Koroukian SM, Schiltz N, Warner DF, et al. Combinations of chronic conditions, functional limitations, and geriatric syndromes that predict health outcomes. J Gen Intern Med 2016:1-8.

7. Hochman M, Asch SM. Disruptive models in primary care: caring for high-needs, high-cost populations, J Gen Intern Med 2017;32(4):392397.

8. Bodenheimer T, Berry-Millett R. Follow the money-controlling expenditures by improving care for patients needing costly services. N Engl J Med 2009;361(16): 1521-1523.

9. Bindman AB, Grumbach K, Osmond D, et al. Preventable hospitalizations and access to health care. JAMA 1995;274(4):305-311.

10. Agency for Healthcare Research and Quality. Guide to Prevention Quality Indicators: Hospital Admission for Ambulatory Care Sensitive Conditions. Agency for Healthcare Research and Quality, 2006.

11. Wasson JH, Sauvigne AE, Mogielnicki RP, et al. Continuity of outpatient medical care in elderly men: a randomized trial. JAMA 1984;252(17):2413-2417.

12. Stange KC, Nutting PA, Miller WL, et al. Defining and measuring the patient-centered medical home. J Gen Intern Med 2010;25(6):601-612.

13. Rosland A-M, Nelson $\mathbf{K}$, Sun $\mathbf{H}$, et al. The patient-centered medical home in the Veterans Health Administration. Am J Manag Care 2013;19(7):e263-272.

14. Coleman EA, Parry C, Chalmers S, Min SJ. The care transitions intervention: results of a randomized controlled trial. Arch Intern Med 2006;166(17):1822-1828.

15. Jack BW, Chetty VK, Anthony D, et al. A reengineered hospital discharge program to decrease rehospitalization: a randomized trial. Ann Intern Med 2009;150(3): 178-187.

16. Hong CS, Siegel AL, Ferris TG. Caring for high-need, high-cost patients: what makes for a successful care management program? Issue Brief (Commonw Fund) 2014;19:1-19.

17. Hong CS, Abrams MK, Ferris TG. Toward increased adoption of complex care management. N Engl J Med 2014;371(6):491-493.

18. Bott DM, Kapp MC, Johnson LB, Magno LM. Disease management for chronically ill beneficiaries in traditional medicare. Health Aff (Millwood) 2009;28(1):86-98.

19. Hickam DH, Weiss JW, Guise J-M, et al. Outpatient case management for adults with medical illness and complex care needs. Agency for Healthcare Research and Quality Effective Health Care Program, Comparative Effectiveness Review \#99, 2013.

20. Rosenthal MB, Friedberg MW, Singer SJ, Eastman D, Li Z, Schneider EC. Effect of a multipayer patient-centered medical home on health care utilization and quality: the Rhode Island chronic care sustainability initiative pilot program. JAMA Intern Med 2013;173(20):1907-1913.

21. Fifield J, Forrest DD, Martin-Peele $\mathbf{M}$, et al. A randomized, controlled trial of implementing the patient-centered medical home model in solo and small practices. J Gen Intern Med 2013;28(6):770-777.

22. Nutting PA, Miller WL, Crabtree BF, Jaen CR, Stewart EE, Stange KC. Initial lessons from the first national demonstration project on practice transformation to a patient-centered medical home. Ann Fam Med 2009;7(3):254-260.

23. Friedberg MW, Schneider EC, Rosenthal MB, Volpp KG, Werner RM. Association between participation in a multipayer medical home intervention and changes in quality, utilization, and costs of care. JAMA 2014;311(8):815-825.

24. Milstein A, Gilbertson E. American medical home runs. Health Aff (Millwood) 2009;28(5):1317-1326. 
25. Yee T, Lechner A, Carrier E. High-Intensity Primary Care: Lessons for Physician and Patient Engagement. 2012; October 2012:1-7. http:// nihcr.org/analysis/improving-care-delivery/prevention-improvinghealth/high-intensity-primary-care/. Accessed 21 Jul 2017.

26. Peterson $\mathbf{K}$, Heland $\mathbf{M}$, Humphrey $\mathbf{L}$, Christensen V, Carson $\mathbf{S}$. Evidence brief: effectiveness of intensive primary care programs. VA-ESP Project \#09-199; 2013.

27. Starfield B, Shi L, Macinko J. Contribution of primary care to health systems and health. Milbank Q 2005;83(3):457-502.

28. Higgins JP, Altman DG, Gotzsche PC, et al. The Cochrane Collaboration's tool for assessing risk of bias in randomised trials. BMJ 2011;343:d5928.

29. McDonagh M, Jonas D, Gartlehner G, et al. Methods for the drug effectiveness review project. BMC Med Res Methodol 2012;12(1):140.

30. Berkman ND, Lohr KN, Ansari M, et al. Grading the strength of a body of evidence when assessing health care interventions for the effective health care program of the agency for healthcare research and quality: an update methods guide for effectiveness and comparative effectiveness reviews. 2013.

31. Beland F, Bergman $\mathbf{H}$, Lebel $\mathbf{P}$, et al. A system of integrated care for older persons with disabilities in Canada: results from a randomized controlled trial. J Gerontol A Biol Sci Med Sci 2006;61(4):367-373.

32. Boult C, Boult LB, Morishita L, Dowd B, Kane RL, Urdangarin CF. A randomized clinical trial of outpatient geriatric evaluation and management. J Am Geriatr Soc 2001;49(4):351-359.

33. Coleman EA, Grothaus LC, Sandhu N, Wagner EH. Chronic care clinics: a randomized controlled trial of a new model of primary care for frail older adults. J Am Geriatr Soc 1999;47(7):775-783.

34. Counsell SR, Callahan CM, Clark DO, et al. Geriatric care management for low-income seniors: a randomized controlled trial. JAMA 2007;298(22):2623-2633.

35. Fairhall N, Sherrington C, Kurrle SE, et al. Economic evaluation of a multifactorial, interdisciplinary intervention versus usual care to reduce frailty in frail older people. J Am Med Dir Assoc 2015;16(1):41-48.

36. Hughes SL, Cummings J, Weaver F, Manheim LM, Conrad KJ, Nash K. A randomized trial of Veterans Administration Home Care for Severely Disabled Veterans. Med Care 1990;28(2):135-145.

37. Hughes SL, Weaver FM, Giobbie-Hurder A, et al. Effectiveness of teammanaged home-based primary care: a randomized multicenter trial. JAMA 2000;284(22):2877-2885.

38. Melin AL. A randomized trial of multidisciplinary in-home care for frail elderly patients awaiting hospital discharge. Aging (Milan, Italy). 1995; 7(3):247-250.

39. Sledge WH, Brown KE, Levine JM, et al. A randomized trial of primary intensive care to reduce hospital admissions in patients with high utilization of inpatient services. Dis Manag 2006;9(6):328-338.

40. Zulman DM, Pal Chee C, Ezeji-Okoye SC, et al. Effect of an intensive outpatient program to augment primary care for high-need Veterans Affairs Patients: a randomized clinical trial. JAMA Intern Med 2017;177(2):166-175.

41. Ekdahl AW, Wirehn AB, Alwin J, et al. Costs and effects of an Ambulatory Geriatric Unit (the AGe-FIT Study): a randomized controlled trial. J Am Med Dir Assoc 2015;16(6):497-503.

42. Jiwa M, Gerrish K, Gibson A, Scott H. Preventing avoidable hospital admission of older people. Br J Community Nurs 2002;7(8):426-431

43. Meret-Hanke LA. Effects of the program of all-inclusive care for the elderly on hospital use. Gerontologist 2011;51(6):774-785

44. Vilà A, Villegas E, Cruanyes J, et al. Cost-effectiveness of a Barcelona home care program for individuals with multimorbidity. J Am Geriatr Soc 2015;63(5):1017-1024.

45. Edwards ST, Saha S, Prentice JC, Pizer SD. Preventing hospitalization with Veterans affairs home-based primary care: which individuals benefit most? J Am Geriatr Soc. 2017.

46. O'Toole TP, Johnson EE, Aiello R, Kane V, Pape L. Tailoring care to vulnerable populations by incorporating social determinants of health: the Veterans Health Administration's "homeless patient aligned care team" program. Prev Chronic Dis 2016;13:E44.

47. Ritchie C, Andersen R, Eng $\mathbf{J}$, et al. Implementation of an interdisciplinary, team-based complex care support health care model at an Academic Medical Center: impact on health care utilization and quality of life. PLoS One 2016;11(2):e0148096.

48. Schubert CC, Myers LJ, Allen K, Counsell SR. Implementing geriatric resources for assessment and care of elders team care in a Veterans Affairs Medical Center: lessons learned and effects observed. J Am Geriatr Soc 2016;64(7):1503-1509.
49. Veterans Health Administration, Geriatrics and Extended Care. Home based primary care technical manual. 2009:1-33.

50. Katz S, Ford AB, Moskowitz RW. Studies of illness in the Aged. The index of ADL: a standardize measure of biological and psychosocial function. JAMA 1963;185:914.

51. Hébert R, Carrier R, A. Bilodeau The functional autonomy measurement system (SMAF [Système de mesure de l'autonomie fonctionnelle]): description and validation of an instrument for the measurements of handicaps. Age Ageing. 1988;17:293-302.

52. Boult C, Dowd B, McCaffrey D, Boult L, Hernandez R, Krulewitch H. Screening elders for risk of hospital admission. J Am Geriatr Soc 1993;41(8):811-817.

53. Coleman EA, Wagner EH, Grothaus LC. Predicting hospitalization and functional decline in older health plan enrollees: Are administrative data as accurate as self-report? J Am Geriatr Soc 1998;46:419-425.

54. VonKorff MV, Wagner EH, Saunders K. A chronic disease from automated pharmacy data. J Clin Epidemiol 1992;45:197-203.

55. Fried LP, Tangen CM, Walston J, et al. Frailty in older adults: evidence for a phenotype. J Gerontol Series A Biol Sci Med Sci 2001;56A(3):M146M156.

56. Wang L, Porter B, Maynard C, et al. Predicting risk of hospitalization or death among patients receiving primary care in the Veterans Health Administration. Med Care 2013;51(4):368-373.

57. Bergman $\mathbf{H}$, Beland $\mathbf{F}$, Lebel $\mathbf{P}$, et al. Care for Canada's frail elderly population: fragmentation or integration? Can Med Assoc J 1997;157(8): 1116-1121.

58. Counsell SR, Callahan CM, Buttar AB, Clark DO, Frank KI. Geriatric Resources for Assessment and Care of Elders (GRACE): a new model of primary care for low-income seniors. J Am Geriatr Soc 2006;54(7):11361141.

59. Mooney C, Zwanziger J, Phibbs CS, Schmitt S. Is travel distance a barrier to veterans' use of VA hospitals for medical surgical care? Soc Sci Med 2000;50(12):1743-1755.

60. Gawande A. The hot spotters: can we lower medical costs by giving the neediest patients better care? New Yorker (New York, NY: 1925). 2011:4051 .

61. MedPAC. March 2012 Report to the Congress: Medicare Payment Policy. 2012:1-443

62. Milstein A, Kothari PP. Are higher value care models replicable? Health Aff Blog 2009.

63. Blash L, Chapman S, Dower C. The Special care center - a joint venture to address chronic disease. http://www.iorahealth.com/wp-content/ uploads/2014/07/UCSF_The_Special_Care_Center_A_Joint_Venture_ to Address Chronic Disease.pdf, 2010. Last accessed 21 Jul 2017.

64. Green SR, Singh V, O'Byrne W. Hope for New Jersey's city hospitals: the Camden initiative. Perspect Health Inf Manag. 2010;7(Spring): 1d.

65. Meltzer DO, Ruhnke GW. Redesigning care for patients at increased hospitalization risk: the comprehensive care physician model. Health Aff (Millwood) 2014;33(5):770-777

66. Guise J-M, Chang C, Viswanathan M, et al. Agency for Healthcare Research and Quality Evidence-based Practice Center methods for systematically reviewing complex multicomponent health care interventions. J Clin Epidemiol 2014;67(11):1181-1191.

67. Stange K, Glasgow R. Considering and reporting important contextual factors in research on the patient-centered medical home. Agency Healthc Res Qual. 2013.

68. Kahwati L, Jacobs S, Kane H, Lewis M, Viswanathan M, Golin CE. Using qualitative comparative analysis in a systematic review of a complex intervention. Syst Rev 2016;5(1):1.

69. Cohen DJ, Crabtree BF, Etz RS, et al. Fidelity versus flexibility: translating evidence-based research into practice. Am J Prev Med 2008;35(5):S381-S389.

70. Pawson R, Tilley N. Realistic Evaluation. London: SAGE; 1997.

71. Zulman DM, Ezeji-Okoye SC, Shaw JG, et al. Partnered research in healthcare delivery redesign for high-need, high-cost patients: development and feasibility of an Intensive Management Patient-Aligned Care Team (ImPACT). J Gen Intern Med 2014;29(4):861-869.

72. Breland JY, Asch SM, Slightam C, Wong A, Zulman DM. Key ingredients for implementing intensive outpatient programs within patient-centered medical homes: a literature review and qualitative analysis. Healthcare 2016;4(1):22-29.

73. Zucco LJ, Urato C, McCall N, et al. Evaluation of the Extended Medicare Care Management for High Cost Beneficiaries (CMHCB) demonstration: Massachusetts General Hospital (MGH). 2013. 